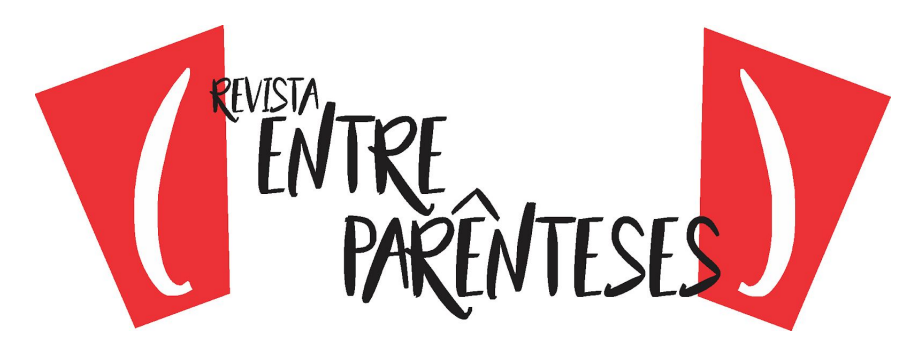

\title{
ABORDAGEM HISTORIOGRÁFICA DA HISTÓRIA DA PENÍNSULA IBÉRICA MEDIEVAL E DA INFLUÊNCIA CULTURAL ÁRABE NO BRASIL
}

\author{
Elenice Maria Caixeta ${ }^{1}$ \\ Universidade Federal de Alfenas - UNIFAL \\ Professora de Educação Básica \\ (elenice_caixeta@yahoo.com)
}

\begin{abstract}
Resumo: Este trabalho objetiva fazer uma revisão bibliográfica acerca da relação cultural entre árabes e cristãos na Península Ibérica Medieval, bem como observar como alguns autores tratam da vinda de uma influência cultural árabe para o Brasil através do processo de colonização. Como forma de compreender as relações culturais na Península Ibérica medieval observamos a questão de alteridade e (in)tolerância nas relações entre os povos. Os resultados mostraram que a convivência entre diferentes culturas na Península Ibérica medieval e no Brasil não foi sinônimo de igualdade, ao contrário, é a da distinção, do reconhecimento à diferença.
\end{abstract}

Palavras-chave: Península Ibérica Medieval; Influência cultural árabe no Brasil; Alteridade.

\section{HISTORIOGRAPHIC APPROACH TO THE MEDIEVAL IBERIAN PENINSULA'S HISTORY AND ARABIC CULTURAL INFLUENCE IN BRAZIL}

\begin{abstract}
This work aims to make a bibliographical review about the cultural relationship between arabs and christians in the Medieval Iberian Peninsula, and to observe how some authors approach aspects of the arrival of Arab cultural influence to Brazil through the colonization process. For to understanding cultural relations in the medieval Iberian Peninsula we look at the question of alterity and (in) tolerance in relations between peoples. The results showed that the living together between different cultures in the medieval Iberian Peninsula and Brazil was not synonymous with equality on the contrary it is that of distinction of recognition of difference.
\end{abstract}

Keywords: Medieval Iberian Peninsula; Arab cultural influence in Brazil; Alterity.

\section{ENFOQUE HISTORIOGRÁFICO DE LA HISTORIA DE LA PENÍNSULA IBÉRICA MEDIEVAL Y DE LA INFLUENCIA CULTURAL ÁRABE EN BRASIL}

Resumen: Este trabajo tiene como objetivo hacer una revisión bibliográfica sobre la relación cultural entre árabes y cristianos en la Península Ibérica medieval, así como observar como algunos autores abordan la llegada de una influencia cultural árabe en Brasil a través del proceso de colonización. Como una forma de entender las relaciones culturales en la península ibérica medieval, consideramos la cuestión de la alteración y la (in) tolerancia en las relaciones entre los pueblos. Los resultados mostraron que la convivencia entre diferentes culturas en la península ibérica medieval y en Brasil no era sinónimo de igualdad, por el contrario, era la distinción, el reconocimiento de la diferencia.

Palabras clave: Península Ibérica Medieval; Influencia cultural árabe en Brasil; Alteridad

\footnotetext{
${ }^{1}$ Mestra em História Ibérica pelo Programa de Pós-Graduação em História Ibérica, mestrado profissional, pela Universidade Federal de Alfenas - UNIFAL. Professora de Educação Básica pela SEMED - Patos de Minas - MG e pela SRE-MG.
} 


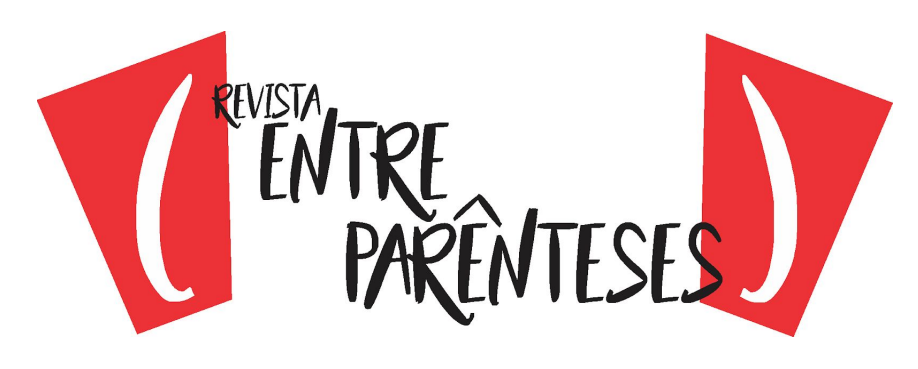

\section{INTRODUÇÃO}

Quando se fala em História Ibérica, o domínio árabe na Península Ibérica medieval deixou influências de diversas formas, por meio da permanência por cerca de oito séculos destes na Península Ibérica que deixaria marcas definitivas no ocidente, como traços de sua cultura que mais tarde viria para a América portuguesa. Com relação a uma cultura árabe, não é possível falar de uma influência cultural árabe no Brasil sem mencionar a influência de um Portugal medieval em nossa cultura.

Este trabalho objetiva fazer uma revisão bibliográfica acerca da relação cultural entre árabes e cristãos ${ }^{2}$ na Península Ibérica Medieval, bem como observar como alguns autores tratam da vinda de uma influência cultural árabe para o Brasil através do processo de colonização. Como forma de compreender as relações culturais na Península Ibérica medieval nesta revisão bibliográfica observamos a questão de alteridade e (in)tolerância nas relações entre os povos que adentraram a Península Ibérica, em 711, com os povos que ali já viviam.

\section{RELAÇÕES DE ALTERIDADE E (IN)TOLERÂNCIA NA PENÍNSULA IBÉRICA MEDIEVAL A PARTIR DO SÉCULO VIII: MUÇULMANOS, CRISTÃOS E JUDEUS}

O termo alteridade pode ser definido como as relações com as diferenças. A alteridade é o reconhecimento da diferença, significa "ser outro, colocar-se ou constituir-se como outro". A lógica da alteridade é reduzir o outro ao "mesmo", ou seja, a si mesmo. O dicionário Aurélio traz a seguinte definição de alteridade: "al.te.ri.da.de - (francês alterité) - substantivo feminino - 1. Qualidade do que é outro ou do que é diferente. - 2. [Filosofia]. Caráter diferente, metafisicamente." A palavra

2 Observamos que alguns autores tratam também da presença de judeus na Península Ibérica Medieval. 


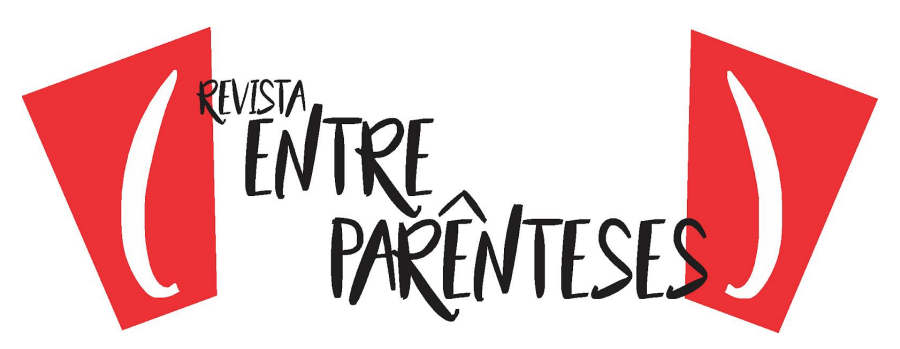

alteridade advém do vocábulo latino alteritas, que significa ser o outro, ou seja, designa o exercício de colocar-se no lugar do outro, de perceber o outro como uma pessoa singular e subjetiva.

Neste sentido, quando nos encontramos diante das diferenças ocorre à compreensão de si mesmo. Em outras palavras, para definir o que somos é preciso saber o que não somos, e isto ocorre a partir do contato como o outro. Construímos nossa identidade por meio da figura do "outro". Neste sentido Agnolin cita Marc Augé (1995, p. 162-3), que trata de uma alteridade múltipla. Para ele

[...] alteridade completa, a do estrangeiro ao qual são atribuídas, se for necessário, todas as taras cuja presença é negada no próprio país: no estrangeiro, que está além das fronteiras, são eventualmente projetados os fantasmas de ferocidade, de canibalismo, de não-humanidade. [...] Existe a alteridade interna, a alteridade social, que a bem dizer é consubstancial ao social definido como sistema de diferenças instituídas: o sexo, a filiação, a posição na ordem dos nascimentos, a idade... [...]. Existe, enfim, a alteridade [...] 'íntima' porque atravessa a pessoa de cada indivíduo. [...] $O$ indivíduo é por definição heterogêneo. A relação está no coração da identidade. A alteridade e a identidade não são concebíveis uma sem a outra (AUGÉ apud AGNOLIN, 2005, p. 182).

A partir de Agnolin (2005) compreendemos que a identidade é "inventada" a partir da relação com o outro. Identidade e alteridade se dão ao mesmo momento. No entanto, a identidade se dá com o diferente, somos aquilo que não somos, o "eu" se define perante o "outro". Como exemplo podemos dizer que o cristão se define como tal perante o muçulmano, bem como o muçulmano se define como tal perante o cristão. E esta relação do "eu" e do "outro" se deu desde a antiguidade, passando pelo medievo, modernidade e está presente na contemporaneidade.

O contato entre diferentes é passível de uma compreensão ou de uma rejeição. Assim, o encontro entre muçulmanos, cristãos e judeus na Península 


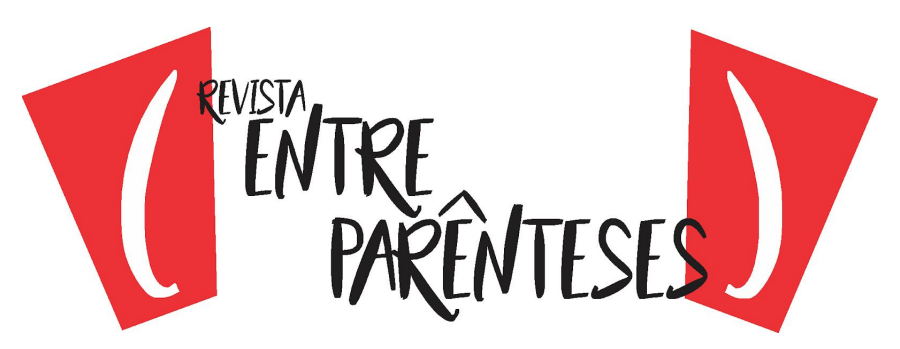

Ibérica $^{3}$ a partir do século VIII não foi diferente. A compreensão ocorre apenas quando se reconhece o outro enquanto completamente distinto do eu que o concebe, o que implica, não apenas no reconhecimento da alteridade, mas do respeito a ela. Para que ocorra compreensão não pode haver hierarquização entre os sujeitos que são distintos e que coexistem no mesmo plano.

À expansão muçulmana, no fim do século VI iniciou-se por meio de uma grande ampliação dos domínios árabes, impulsionada principalmente pela religião islâmica professada pelo profeta Muhammad ibn Abdallah, Maomé. Após a morte deste em 632 d. C., os domínios árabes expandiram-se por toda a Península Arábica ${ }^{4}$ e em 645 o califado árabe já dominava a Síria, a Palestina, o Egito e a Líbia. Estendendo no fim do século VII por toda a África do Norte. Os árabes levaram pouco mais de cem anos para estender sua religião, língua e domínio político. Neste sentido Macedo afirma que

[...] a expansão político-religiosa iniciada no século VII da era cristã pelos califas muçulmanos da dinastia omíada levou o credo corânico dos confins do deserto da Arábia até os limites meridionais do continente europeu. Entre 630 e 640 os adeptos da pregação de Maomé incorporaram territórios situados no Iraque, Irã, Pérsia e parte do Império Bizantino. Depois da conquista da Síria e Mesopotâmia, alargaram suas conquistas rumo ao Ocidente através do Norte da África, incorporando Alexandria, Trípoli, e depois as tribos de berberes dos atuais Tunísia e Marrocos (MACEDO, 2004, p. 132).

É a religião islâmica que promove a unificação entre os primeiros grupos tribais da Arábia, bem como garantem ao longo do tempo a sua expansão e

\footnotetext{
${ }^{3}$ Em relação aos povos que adentraram a Península Ibérica Medieval não há uma denominação que possua um consenso. Câmara Cascudo ressalta que "não dizíamos árabe ou sarraceno, mas mouro, o nome mais constante na península lbérica, lembrando os berberes, mouros históricos, reinando na Espanha, vivos na recordação lusitana" (CÂMERA CASCUDO, 1967, p. 17). José Rivair Macedo afirma que "em Portugal, Espanha e América luso-espanhola não se diz "cristãos e muçulmanos" nem "cristãos ou islâmicos", mas "cristãos e mouros", ou "cristãos e turcos" [...]" (MACEDO, 2004, p. 132). O que revela uma diversidade de caráter étnico, e não apenas de cunho religioso, entre os povos que habitavam a Península Ibérica entre os séculos VIII - XV.

${ }^{4}$ A Arábia é uma península da Ásia Ocidental, próxima da África, que se limita a noroeste com a Palestina, ao sul com o oceano Índico, a leste com o golfo Pérsico e a oeste com o mar Vermelho.
} 


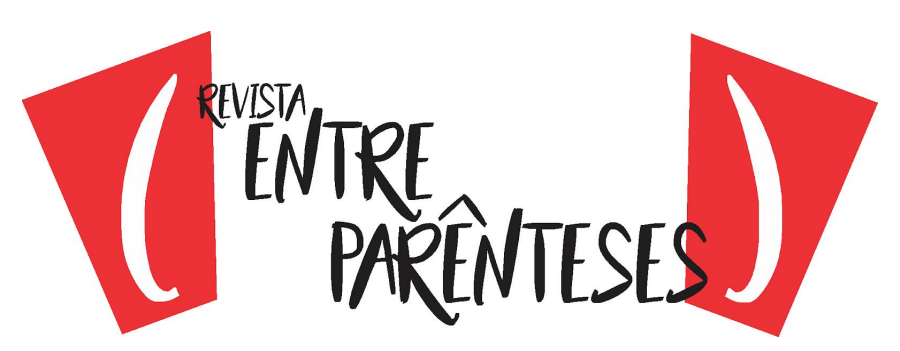

hegemonia sobre os povos conquistados. Neste sentido, Eduardo Manzano Moreno afirma que

los miembros del ejército conquistador estaban unidos por una fuerte conciencia de etnicidad común y por saberse los recipendiários de un mensaje salvacional que les había permitido conquistar medio mundo. Esse mensaje incitaba a someterse y a adorar al Dios único y verdadero, pero estaba lejos de instigar a la subversión del orden social (MORENO, 2011, p. 115).

Por meio destes ideais, no princípio do século VIII um pequeno exército composto de árabes, orientais e berberes, chefiado pelo general Tariq Ibn Ziad cruzou o estreito de Gibraltar, no Norte da África, chegando a Península Ibérica vencendo Rodrigo (último rei da Espanha Visigoda) na Batalha de Guadalete. Em pouco tempo as tropas de Tariq cercavam Córdova, assim "mouros e árabes ocupam a Península Ibérica em uma extensão até então desconhecida: surge Al-Andalus" (NOGUEIRA, 2001, p. 279).

Como fator facilitador do avanço muçulmano na Península Ibérica pode-se ressaltar o traçado das vias romanas e a atitude dos povos visigodos perante o domínio árabe. Outro fator que favoreceu a presença árabe na Península Ibérica foi à crise político-religiosa da monarquia visigoda. Neste sentido, Costa (2006) ressalta a condição da população Hispânica frente à dominação visigótica.

A Hispânia visigótica vivia envolta em lutas dinásticas e revoltas populares. As degradantes condições sociais e econômicas a que o povo estava sujeito, fomentavam um clima de opressão e desigualdades crescentes. No plano religioso, professava-se um Cristianismo de pendor arianista, hostil às concepções trinitárias do rito e liturgia romana. Por outro lado, a minoria judaica era vítima de grande hostilidade e perseguições. Compreende-se, por isso, a aceitação por parte da população de um novo poder político (COSTA, 2006, p. 156). 


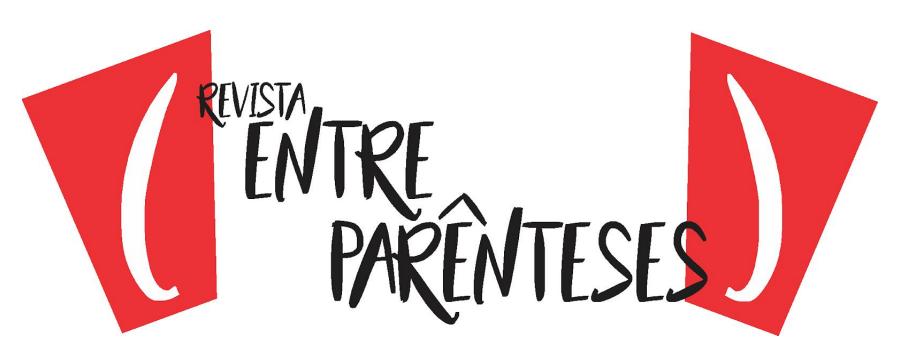

No entanto, na Península Ibérica medieval, por um período de oito séculos (VIII-XV) observam-se períodos de harmonia e tolerância, intercalados por períodos de tensão e intolerância religiosa. As relações entre as diferentes comunidades eram regidas por alianças e acordos. Com relação aos muçulmanos, a princípio era uma sociedade que governavam uma maioria não muçulmana que

[...] foi se transformando numa sociedade em que a maior parte da população aceitava a religião e a língua dos governantes, e um poder que governava a princípio de um modo descentralizado foi se tornando, por manipulação política, um poder poderosamente centralizado, governando mediante 0 controle burocrático (HOURANI, 2006, p. 69).

Controle burocrático por meio da cobrança de tributos, um exemplo são as populações cristãs mais resistentes do norte, populações que para garantir sua autonomia viam-se obrigadas ao pagamento de tributos para conservarem as suas terras e bens, o chamado kharaj, e para manterem a sua religião era necessário o pagamento da jizya. E os que aceitam sujeitar-se à dominação islâmica, mas continuavam a professar a sua fé cristã, denominavam-se por moçárabe (COSTA, 2006, p. 156-157). No que diz respeito a esta população do norte, Rucquoi (1995, p. 75) afirma que "no decorrer da segunda metade do século IX, numerosos cristãos emigraram para o Norte enquanto outros se fundiam cada vez mais na sociedade, adaptando os trajes, a língua dos muçulmanos e, por vezes, até sua religião".

Neste sentido, Silveira (2009) afirma que a diversidade cultural europeia pode ser fundamentada desde a Idade Média através do convívio e trocas culturais entre cristão, judeus e muçulmanos. No entanto, Silveira afirma que a divisão da Península Ibérica em duas partes (uma cristã ao Norte e uma muçulmana ao sul) não pode servir como única explicação para a formação cultural desta região.

As trocas culturais na Península lbérica - e na região mediterrânica em geral - foram tão intensas que a categorização e a identificação 


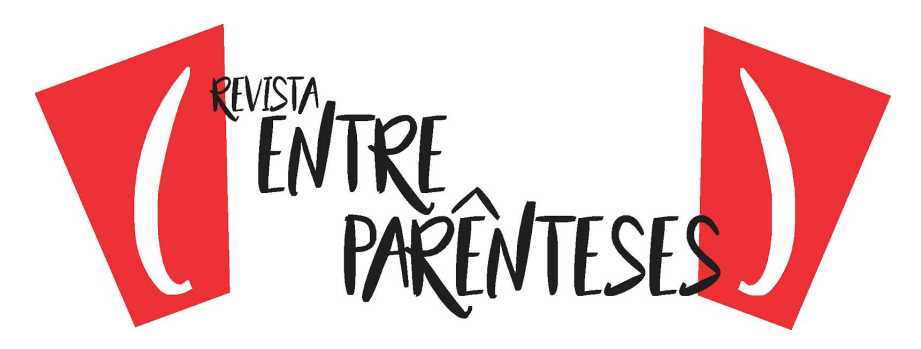

de elementos culturais próprios de uma determinada cultura dificilmente serão absolutas. A convivência entre muçulmanos espanhóis e norte-africanos em Andaluzia não consistiu na dominância da cultura andaluza no Magreb, bem como não evidencia a supremacia dos ensinamentos almorávidas. Trata-se, neste caso, de um tipo de entrelaçamento, que deu origem a um novo desenvolvimento e ao surgimento de espaços de liberdade e de conflitos (SILVEIRA, 2009, p. 651).

Desta forma, não se consegue definir a realidade das trocas culturais nas regiões mediterrâneas, devido essas trocas terem ocorrido em diversos sentidos e direções. Silveira fala no surgimento, na Península Ibérica, de novos sistemas em um período de longa duração e não de um processo de importação ou exportação de elementos culturais. Em oposição à ideia de uma unidade no espaço cultural evidenciou-se o intercâmbio cultural, as trocas culturais dentro da Península no período medieval. Com relação à diferença e a diversidade, a Península Ibérica Medieval teria sido constituída através das relações entre os seguidores das três religiões monoteístas: cristianismo, judaísmo e islamismo.

Pois, em nenhum lugar da Europa viveram tantos muçulmanos, judeus e cristãos juntos e, exatamente por este motivo, a Península nos apresenta tantos exemplos de contradição, como tolerância e rechaço, cooperação e perseguição, respeito e desprezo, alianças e guerras, testemunhos claros da diversidade europeia (SILVEIRA, 2009, p. 654).

Silveira apresenta como resultado do contato destas três culturas monoteístas: "entrelaçamento, apropriação, concorrência e, em consequência disso, a diferenciação perante o outro, ou seja, a construção de identidades" (SILVEIRA, 2009, p. 654). Desta forma, o cristianismo, o judaísmo e o islã contribuíram para a construção dos valores e da cultura europeia. Observando que a cultura está em constante movimento, o qual é impulsionado pelos processos de troca culturais, sejam estas trocas pacificas ou conflituosas. E este contato cultural deu origem a 


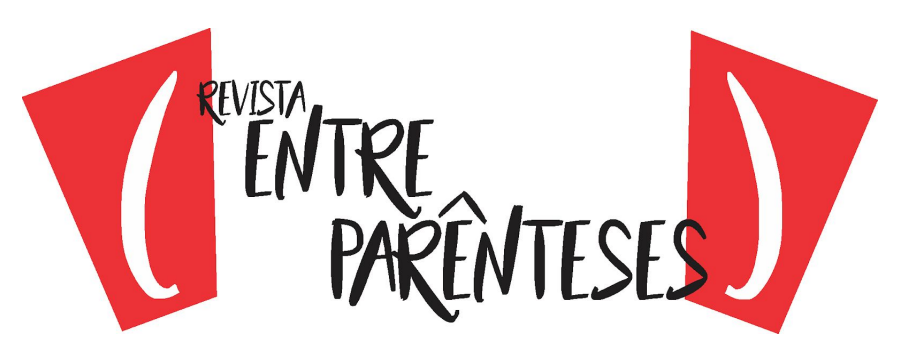

uma intelectualidade única. Neste sentido, com relação ao mundo mulçumano, Rucquoi (1995, p. 108) afirma que

[...] se a adversidade está na origem das perturbações que puseram mais de uma vez a sua unidade política em perigo antes de levar a sua divisão em reinos de taifas, ela é igualmente a origem de uma vida intelectual sem igual, em que os membros das três grandes comunidades religiosas e linguísticas prosseguiram ou criaram uma obra filosófica, artística, literária e científica de que a Europa setentrional dos séculos XII e XIII iria beneficiar.

No tocante ao conhecimento árabe construído na Península Ibérica medieval do século VIII ao século XV, Alfonso-Goldfarb ressalta o trabalho de tradução, pesquisa, estudos e debates praticados por árabes em bibliotecas. Observa-se que este trabalho de pesquisa deu origem a importantes trabalhos que tratam do conhecimento de música, medicina, filosofia, alquimia, química, entre outros que foram desenvolvidos por árabes durante a Idade Média, assim

[...] a cultura e a ciência árabes não se constituíam de meras traduções clássicas, desconexas e empilhadas em velhas bibliotecas-arquivo, nos dão prova os manuscritos sobre essências (perfumes e venenos) de Al-Kindi; a Canon médico de Avicena: a alquimia de Al-Razes; a ótica geométrica de alhazen e a astronomia de al-Biruni, para dar somente uma pequena amostra da quase infindável constelação do saber islâmico. Para um ângulo mais prático são também encontráveis tratados sobre agricultura, irrigação e metalurgia, bem como a constatação da existência de boas instalações hospitalares e de banhos públicos por quase todo mundo árabe (ALFONSO-GOLDFARB, 1991, p. 34).

Apesar de toda efervescência cultural emergindo na Península Ibérica medieval ocorre à deterioração do califado de Córdova, a partir do ano de 1008, ocorrendo assim um enfraquecimento do mundo muçulmano. Lutas de sucessão dinástica e a manifestação de diferentes interesses regionais fez com que ocorresse à fragmentação do território em diversos reinos politicamente independentes entre si, eram os chamados reinos de taifas. 


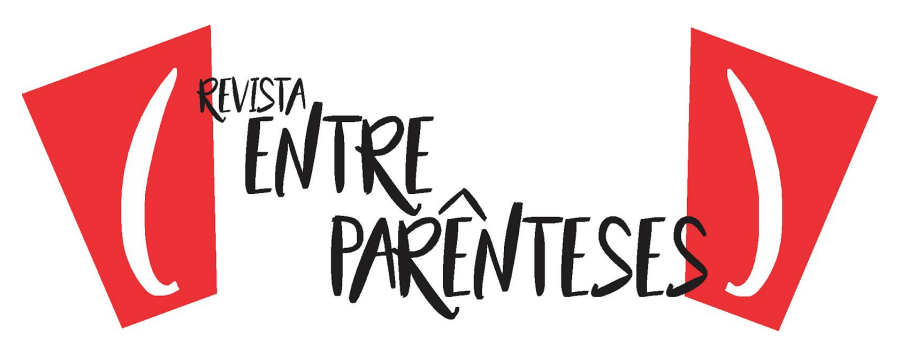

O Estado cordovês perdeu sua estabilidade no princípio do século XI. O último governante de prestígio foi o general Abu Amir Mohammed ibn Zbi Amir, mais conhecido pelo nome de al-Mansur "o vitorioso". Depois dele, as lutas de sucessão dinástica e as divergências internas entre lideranças "sírias", bérberes e os esclavões deram origem a uma torrente de rebeliões locais responsáveis pela desagregação do Estado unitário e pelo aparecimento de dezenas de reinos autônomos, os muluk al-tawaif (reinos de taifas), chefiados por bérberes no sul, eslavos no Leste e por andaluzes (MACEDO, 2004, p. 133, grifo do autor).

Estes reinos de taifas originaram conflitos entre si e com os reinos cristãos. Neste período dá-se início ao lento processo de Reconquista, tendo como liderança os reinos cristãos: Castela, Leão, Navarra e Portugal. No entanto, a Reconquista total dos territórios dominados pelos muçulmanos só ocorreu em 1492, quando a força militar da união dos reinos de Castela e Aragão anexou Granada a seus territórios. Costa afirma que este período foi politicamente frágil, mas rico artístico e cientificamente, verificando-se uma multiplicação dos centros de poder e de cultura (COSTA, 2006, p. 157).

No processo de reconquista ocorre que quando os reinos de Castela e Leão conquistavam territórios muçulmanos era interessante manter-se uma relação econômica entre os mesmos - as chamadas parias ${ }^{5}$. Devido ao fato de que os reinos cristãos inicialmente não tinham a condição de conquista plena daqueles reinos muçulmanos. Com o domínio cristão, os reinos faziam concessões aos vencidos. Era lhes garantindo o direito de manterem seus usos, costumes, língua, religião dentro das cidades retomadas, semelhante o que foi feito pelos muçulmanos anteriormente. Processo que dará origem as aljamas ${ }^{6}$. Contudo, não havia uma

\footnotetext{
${ }^{5}$ Parias é um projeto político e de conquista dos reinos muçulmanos na Península lbérica durante o processo de Reconquista. As parias "consistiam em tributos pagos em ouro pelos reis muçulmanos dos taifas (pequenos reinos muçulmanos localizados no sul da Península Ibérica) aos reinos cristãos do norte para que as relações pacíficas fossem mantidas" (SILVEIRA, 2009, p. 647).

${ }^{6}$ Aljamas são comunidades islâmicas sob domínio cristão, e os integrantes receberam o nome de mudéjares (muçulmanos que viviam em terras sob o domínio cristão). Neste período além dos mudéjares temos também Muladis: cristãos convertidos ao islamismo. Moçárabes: cristãos que
} 


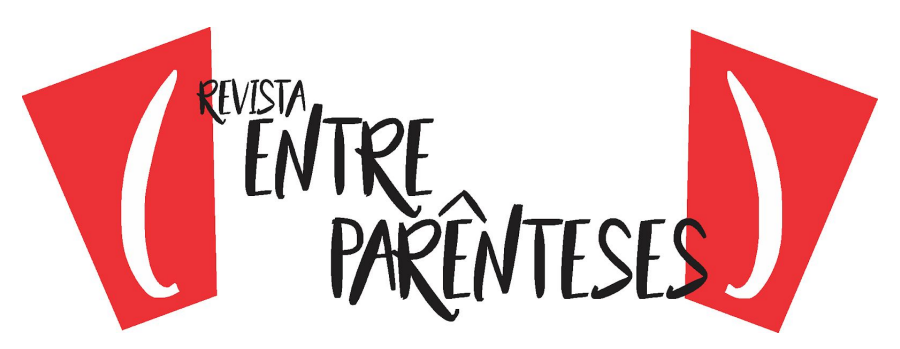

união entre cristãos e muçulmanos, havia era um pagamento de tributos dos muçulmanos para com os cristãos.

Com a retomada de Toledo pelo rei Alfonso VI (1065-1109) de Leão e Castela os reinos taifas estabelecem um tratado com os almorávidas (que governavam Marrocos) contra os reinos cristãos. Nogueira (2001) ressalta que após a invasão fundamentalista dos almorávidas, os enfrentamentos entre cristãos e muçulmanos se radicalizam, tomando o sentido de "cruzada" para os cristãos e Jihâd "guerra santa" para os muçulmanos. No entanto, os almorávidas são "falsos aliados" das taifas, pois se posicionam como conquistadores não respeitando as taifas, e às incorporando a seus territórios. Diante desta situação as taifas se aproximam dos reinos cristãos. Costa (2006, p. 158) relata estes acontecimentos.

Os Cristãos tentavam enfraquecer os reinos muçulmanos através da celebração de acordos, com os quais impunham o pagamento de tributos. Tanto al-Muzaffar, como al-Mutamid, tiveram de pagar a Afonso VI de Castela para manterem a paz. Isto não impediu os reis cristãos de continuarem a atacar os seus territórios. Para os enfrentar, al-Mutamid vê-se obrigado a pedir auxílio a Yûsuf Ibn Tâshfin, emir almorávida no Norte de África. Este desloca-se à península, e acaba mesmo por vencer o rei de Leão e Castela. Mais tarde, o medo que o crescente poder de Yûsuf Tâshfin inspira nos soberanos das taifas, leva a que estes tentem fazer uma aliança com Afonso VI.

Com relação à chegada dos almorávidas em Andaluzia, Silveira (2009, p. 649-650) ressalta que

o povo almorávida era constituído pelo conjunto de tribos berberes nômades, unidas pelos rigorosos ensinamentos sunitas de Abdalah Ibn Yasin, de influência maliquita. Estas tribos conquistaram o norte da África e grande parte da Península Ibérica, chegando à Espanha a pedido do rei muçulmano de Sevilha que, por ocasião da tomada de Toledo pelos cristãos sob a liderança de Afonso VI (1085), vê no apoio das tropas muçulmanas africanas a única alternativa de

viviam em terras sob o domínio muçulmano. Mouriscos: o mesmo que mudéjares. Conversos: judeus ou muçulmanos convertidos ao cristianismo. 


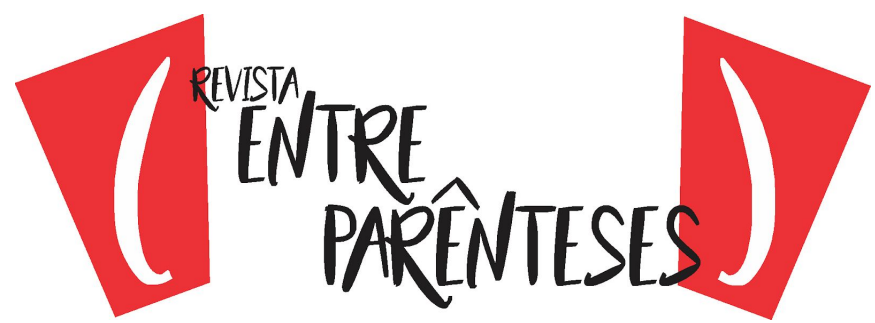

resistência aos cristãos. Os almorávidas chegaram em campanha de guerra contra Afonso VI em 1086, derrotando os cristãos na Batalha de Sagranjas [...]. Os almorávidas não pretendiam, porém, voltar à África. Assim, em um curto espaço de tempo (até 1092), consolidaram seu poder no sul da Península Ibérica através da anexação dos reinos-taifas. A relação entre berberes almorávidas e andaluzes não se configurou de forma pacífica. Os norte-africanos passaram de convidados a indesejados senhores. Nas fontes andaluzas, os almorávidas são descritos como analfabetos incultos e rudes criadores de gado. Autores evidenciam que a rigorosidade dos ensinamentos impostos pelos almorávidas conduziu as cidades andaluzas ao protesto e à resistência, chegando a afirmarem que esta rigorosidade destruiu a antiga cultura oriental que vinha sendo resguardada desde o Califado de Córdova.

Havia um contraste entre os almorávidas quando comparados aos muçulmanos da "Hispania" sendo que a hostilidade de cristãos contra estes contribuíram para o sentimento de cruzada no processo de Reconquista.

Os almorávidas (1042-1145) impuseram um clima de intensa intolerância religiosa, de forma que estes exerceram pressões nas minorias religiosas por razões: ideológicas, políticas e econômicas. O período de dominação almorávida foi frágil e curto. "Entre 1091 e 1117, várias campanhas militares permitiram a tomada de Sevilha, Lisboa, Badajoz, Santarém e de importantes posições em torno de Coimbra, naquilo que foi a derradeira tentativa de expansão para Ocidente desta dinastia" (COSTA, 2006, p. 159). A unificação dos almorávidas incrementou a circulação monetária e uma intensa atividade econômica nos portos do Gharb, em contrapartida, as populações sujeitas a pesados impostos alimentaram um estado de rebelião, levando aos almorávidas a repararem e reforçarem suas muralhas, além de concessões feitas por parte do emir. "A progressão da reconquista cristã foi um sinal claro da decadência desta dinastia. Por volta de 1143, apareceram novos reinos independentes, que ficariam conhecidos pelas segundas taifas" (COSTA, 2006, p. 159).

Divergências entre os almorávidas faz com que estes solicitem ajuda aos almóadas. Estes que acabaram substituindo os almorávidas no Norte da África. Os 


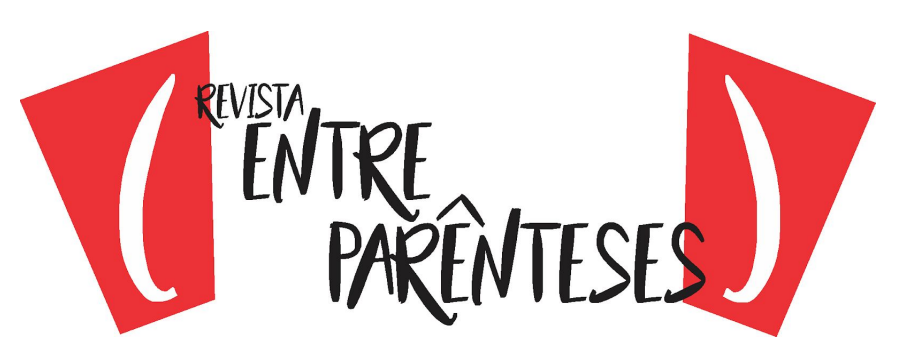

almóadas (1145-1262) em Al-Andalus impuseram sua intransigência e rigidez religiosa, bem como buscaram seguir os impulsos expansionistas dos almorávidas através da militarização da sociedade. Os almóadas conquistam várias cidades, contudo, sua derrota em Navas de Tolosa, no ano de 1212, marcou o avanço final dos reinos cristãos sobre o Alentejo e Algarve. Desta forma, a dominação muçulmana do território que hoje é Portugal começou no século VIII e perdurou até o século XIII, quando os cristãos, em processo de Reconquista, ou de uma conquista, dominaram o Algarve. Dois séculos mais tarde muçulmanos e judeus serão forçados à conversão ou expulsos pelo rei Manuel, que em dezembro de 1496

assina um decreto em que colocam Muçulmanos e Judeus perante a alternativa da expulsão ou conversão. Os Muçulmanos que aceitam a conversão passam a designar-se por Mouriscos. Muitos continuam a praticar o Islão na clandestinidade mas, a partir do reinado de D. João III, serão vítimas da Inquisição. Ao longo dos séculos seguintes, a sua presença em Portugal foi rareando, até deixar de existir relatos sobre a sua existência (COSTA, 2006, p. 164).

Neste sentido, clérigos e soberanos empregaram grande ofensiva contra os reinos muçulmanos, depois contra os seguidores do Islã e por fim contra todos os credos e culturas não cristãs. Com relação à reconquista, o mouro fora expulso do Algarve duzentos e cinquenta anos antes da vinda portuguesa para o Brasil. E, na Espanha, a saída dos muçulmanos levou mais tempo, até 1492, mesmo ano em que Colombo daria início a sua jornada em direção ao "Novo Mundo". A descoberta do "Novo Mundo" pode ser tida como uma continuação da "reconquista cristã". Pois, a legitimidade da conquista da América é afirmada como uma continuação da Reconquista dos territórios espanhóis ocupados.

Ainda falando do processo de reconquista, alguns autores afirmam que esta se mantém na ideia de um retomar de um território que teria uma identidade própria cristã e que havia sido invadido pelos muçulmanos, mas na verdade esta identidade cristã já há muito tempo não existia. Os cristãos afirmam que o processo 


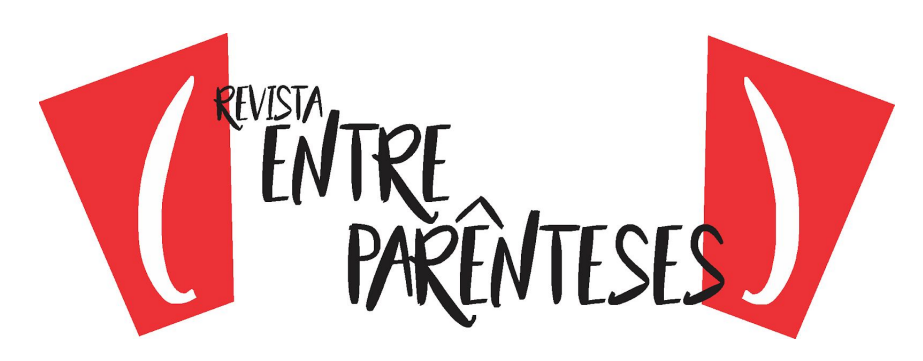

de reconquista está na herança visigótica. E após a conquista de Toledo, em 1085, os reinos de Leão e Castela passam a se apresentar como restauradores da herança visigótica, um desejo de hegemonia ibérica, por meio da reivindicação de uma autoridade transmitida pelo legado dos godos. Era uma forma de legitimação da reconquista. Cria-se assim na Península Ibérica o mito de uma terra cristã ocupada pelos muçulmanos que deveria ser recuperada, ser reconquistada.

A ideia que a Espanha formava uma real unidade, unidade conquistada pelos godos e sancionada pela ordo eclesiástica, com o prestígio especial dos vários Concílios de Toledo, portanto, uma legítima unidade que foi usurpada pelo muçulmano invasor, vai ser lentamente elaborada e testada até constituir, no final do século XIII uma realidade incontestável, que garantia aos cristãos, em especial aos castelhanos, o direito sagrado e historicamente legítimo de possuir e usufruir da Península e no limite, dela expulsar estrangeiros e infiéis (NOGUEIRA, 2001, p. 280, grifo do autor).

As narrativas revelam muito mais nosso tipo de sociedade do que dos sujeitos que estão sendo relatados. As narrativas são reveladoras do sujeito que fala, da sociedade que fala, e não de quem se fala. Falar do outro é um pretexto para falar de nós mesmo. Assim, quando se fala que os muçulmanos invadiram a Península e usurparam uma unidade cristã, na verdade é isto que os cristãos estariam fazendo, invadindo um território que tinham, até certo ponto, uma unidade religiosa e política.

Outro viés empregado ao processo de reconquista é a chegada dos muçulmanos na Península Ibérica medieval vista como uma ideia de castigo pelos pecados dos povos cristãos. Neste sentido Rucquoi (1995, p. 60) afirma que "desde a época medieval que a explicação oficial foi a de uma 'crise moral', e 711 tornou-se uma data emblemática, a do 'castigo' de um reino em virtude dos 'pecados' dos seus governantes".

No entanto, os conflitos entre muçulmanos e cristãos fizeram parte do processo de Reconquista Cristã. Mas, para além dos conflitos ocorridos é certo que 


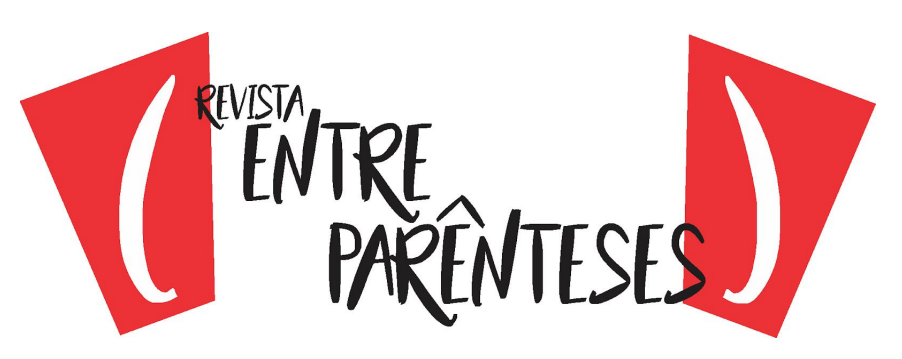

a história de Portugal e Espanha está marcada pela contribuição do mouro à sua cultura, observando uma "[...] redução drástica da distância horizontal ocorrida nesse processo de assimilação da alteridade faz com que esses outros não sejam mais totalmente outros" (AGNOLIN, 2005, p. 188). Contudo, a uma tentativa de fugir ou subestimar esta herança cultural árabe presente na Península Ibérica, mas

[...] jamais poderão se apagar das paredes centenárias de Sintra a marca indelével da cultura mourisca. Jamais poderão desfigurar a arquitetura popular do Algarve, ou fender os monumentos mais célebres de Portugal, todos eles marcados pelas mãos dos artífices mouriscos ou mesmo pôr abaixo aquela Torre de Belém, onde o mourisco se funde ao atlântico-português, como um símbolo das núpcias estilísticas (ORNELLAS apud PORTUGAL, 2011, p. 11).

A dificuldade que se tem em aceitar a influência da cultura árabe na Península Ibérica é reafirmada com a necessidade de se negar "o outro", negar a influência de outras culturas, de uma possibilidade de trocas e enriquecimento cultural. Mas, pode-se falar que em Al-Andalus houve, até certo ponto, uma aceitação do "outro", uma tolerância demonstrada por parte de governantes na época do califado, visto na amena convivência e mestiçagem entre as várias culturas e religiões.

Quanto às trocas culturais ocorridas na Península Ibérica medieval, Silveira (2013) discute o conceito de tolerância na Idade Média numa Europa que coexistia muçulmanos, cristãos e judeus. Silveira ressalta a convivência destes destacando as relações entre estas culturas na corte de Afonso X no século XIII.

Sua corte ficou conhecida pela reunião, convivência e colaboração de intelectuais oriundos de diferentes lugares e credos. Principalmente, nas traduções do árabe para o castelhano, trabalhavam juntos judeus, mouros e cristãos, a construir um reconhecido espaço de trocas culturais na corte afonsina. Neste ambiente cortês, as trocas forma pacíficas e incentivadas pelo monarca patrono das artes. No entanto, esta realidade harmônica poucas vezes atravessou os muros dos castelos e o contato entre 


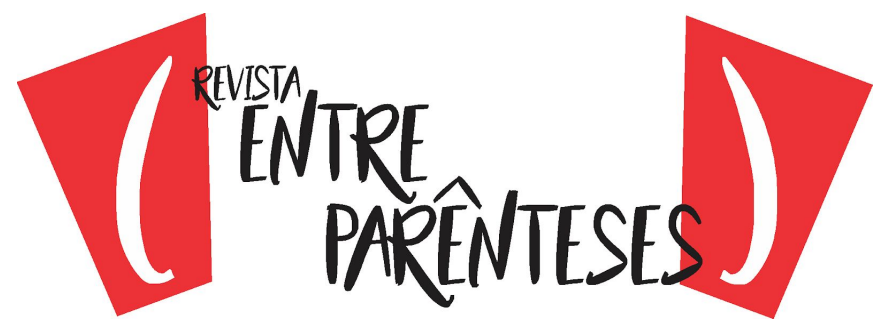

cristãos, muçulmanos e judeus foi restringido, em algumas circunstâncias, rechaçado, mesmo que, na maioria das vezes, inevitável (SILVEIRA, 2013, p. 129).

\section{Na Península Ibérica Medieval}

\begin{abstract}
observa-se, diferentes atitudes frente à mutua influência advinda da coexistência das culturas na forma de confrontação, resistência, aceitação, bem como do entrelaçamento cultural. Influenciar e perceber a influência do "outro" naquilo que reconhecemos como o "nosso" conduz-nos ao sentimento de perda de identidade e de orientação, no entanto, adaptações, fusões e reconstruções são processos inevitáveis nas zonas de fronteira, sejam elas espaciais ou culturais. Ali, onde a separação entre o "nosso" e o "d'outro" são exigidas, emergem também questões à volta do reconhecimento, da aceitação ou do rechaço e, finalmente, a questão das fronteiras da tolerância (SILVEIRA, 2013, p. 132).
\end{abstract}

Fatores importantes para a convivência de diferentes culturas é o reconhecimento do outro e a tolerância. Com relação à prática da tolerância na Península Ibérica muçulmana e cristã, Silveira (2013, p. 136) ressalta que foi "uma tolerância medieval, praticada com pragmatismo para evitar um mal maior, mas que não exclui a possibilidade de reconhecimento do outro como elemento que faz parte de um todo maior, seja nas dimensões do reino ou do monoteísmo".

A interação cultural, a migração e as trocas culturais na Península lbérica medieval foram tão intensas entre povos "(iberos, romanos, visigodos, judeus, muçulmanos africanos, muçulmanos ibéricos, moçárabes, mudéjares e cristãos de outras partes) o que a categorização e a identificação de elementos culturais próprios de uma determinada cultura dificilmente podem ser absolutas" (SILVEIRA, 2013, p.137).

No entanto, não podemos ter uma percepção de convivência romântica deste período, as relações ali estabelecidas eram frutos de sua época, atendendo os anseios culturais ali existentes para manter a ordem nos espaços e se enquadrar nas condições de vida da época. Não que a convivência entre diferentes culturas na 


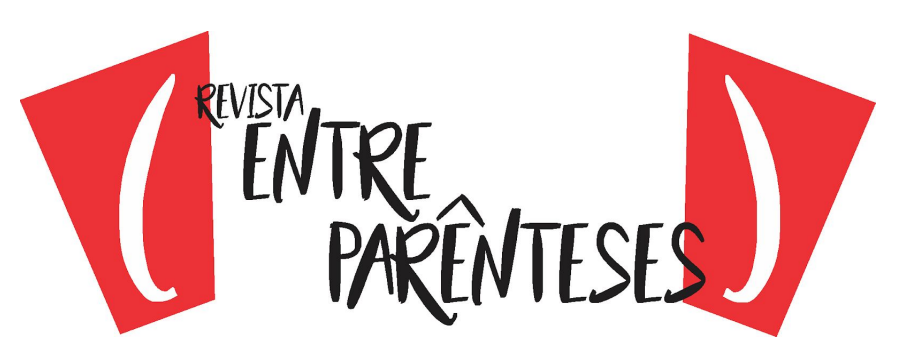

Península Ibérica medieval tenha sido sinônimo de igualdade, ao contrário, é a da distinção, do reconhecimento à diferença. Desta forma, o processo de tolerância abrange os conceitos de construção e desconstrução de identidades dos povos deste período.

A presença de uma cultura árabe no cotidiano brasileiro advém deste período em que árabes estiveram na Península lbérica, cerca de oito séculos, essa cultura árabe veio para o Brasil através do processo de colonização brasileira e se faz presente no nosso dia a dia, desta forma é relevante compreender a interação entre cultura árabe e brasileira, para isso a seguir ressaltaremos alguns pontos da influência cultural árabe no brasil.

\section{RELAÇÕES CULTURAIS NO PROCESSO DE COLONIZAÇÃO BRASILEIRA}

Para compreendermos a origem da cultura brasileira é necessário voltarmos ao processo de colonização, e como exemplo de estudiosos da sociedade brasileira que buscavam no passado, no processo de colonização do Brasil explicações para as características da sociedade brasileira, podemos citar Gilberto Freyre $^{7}$ autor de Casa Grande \& Senzala e Sérgio Buarque de Holanda autor de Raízes do Brasil, ambos os livros publicados na década de 1930.

Freyre atribui o sucesso da colonização brasileira ao fato da

"bicontinentalidade" dos portugueses, tanto cultural quanto étnica; o fato de já terem experiência na colonização de territórios tropicais; a sua mobilidade; a sua miscibilidade, resultante da sua falta de orgulho de raça, por sua vez consequência do fato de já serem um "povo-mistura" de Europa e África; a sua aclimatabilidade, resultante do fato de as condições físicas de solo e de temperatura de Portugal serem mais parecidas com as da África do que com as da Europa (BISCARDI, 2007, p. 4).

\footnotetext{
${ }^{7}$ Quanto a Freyre, José Carlos Reis (1999) afirma que na escrita deste é possível observar afinidades com a sociologia compreensiva de Weber e também de uma vertente alemã, por meio do contato com seu orientador Franz Boas.
} 


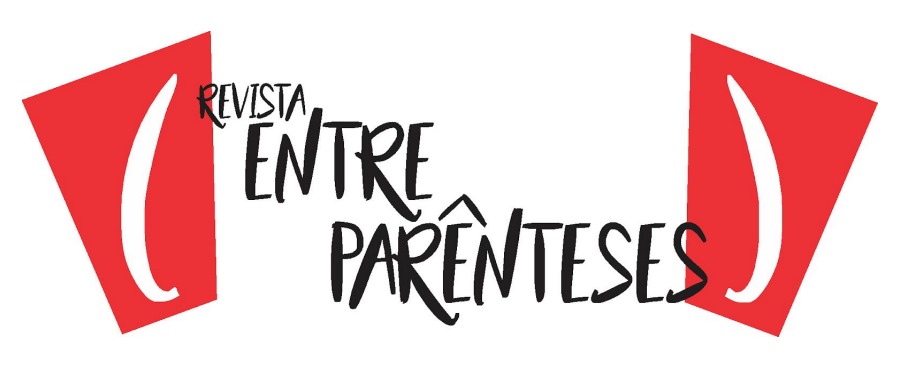

Já Buarque de Holanda ressalta que da Península Ibérica "veio a forma atual de nossa cultura; o resto foi matéria que se sujeitou mal ou bem a essa forma." (BUARQUE DE HOLANDA, 2003, p. 40). Buarque de Holanda ao fazer uma análise de "nossas raízes" observa a importância que a colonização portuguesa teve para a formação da cultura brasileira. Certamente que tais influências não foram às únicas, cabendo ao "índio" e ao negro papel importantíssimo. A formação de nossa cultura foi uma mistura dessas três raças. Só que os portugueses tinham características próprias e influências culturais diversas, como a influência dos povos árabes, por meio da convivência que tiveram por séculos na Península Ibérica. Estas relações foram responsáveis pela formação cultural e política do Brasil.

No entanto, com relação às heranças culturais brasileiras, Franco Júnior faz uma crítica ao livro Raízes do Brasil de Buarque de Holanda, pois, para Franco Júnior, Buarque de Holanda não fez jus ao título da obra, pois não foi a fundo nas raízes do Brasil, que são anteriores a 1500, e apenas se ateve aos acontecimentos pós "descobrimento". Assim o autor diz: "o grande historiador não levou na devida conta, a nosso ver, sua própria metáfora. As raízes do Brasil evidentemente antecedem o Brasil. Elas são anteriores a 1500. Elas encontram-se no período que há muito se convencionou chamar de Idade Média” (FRANCO JÚNIOR, 2008, p. 82). Franco Júnior (2008, p.82) ainda enfatiza que "mais do que na civilização portuguesa moderna, as raízes do Brasil deverão se procurar, portanto, na Europa medieval".

Franco Júnior também questiona a exaltação da figura de um lusitano patriarca e aventureiro (figura também existente no Brasil colônia) que Buarque de Holanda ressalta sem, porém fazer a ligação destas características com o seu caráter medieval e peninsular. $\mathrm{O}$ autor questiona se o motivo para se deixar de lado a contribuição medieval para a formação do Brasil seria o preconceito arraigado com relação à Idade Média. Contudo, como hipótese para esta abordagem de Buarque 


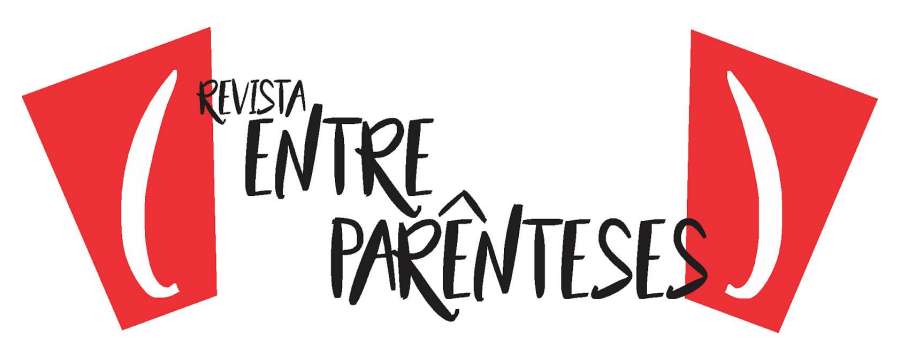

de Holanda esteja o paradigma da historiografia brasileira que ressalta um Brasil herdeiro da cultura dos vencedores.

Como uma das raízes do Brasil podemos citar os 800 anos de presença árabe na Península Ibérica que ocorreram na Idade Média, pois esta presença deixou marcas em portugueses e espanhóis que posteriormente deixará marcas em suas colônias, entre elas o Brasil. Desta forma, a permanência do árabe por tanto tempo na Península Ibérica deixou marcas de sua cultura no imaginário europeu, e muitos elementos medievais foram transportados de Portugal para a América Portuguesa, e ainda hoje permanece traços desta cultura.

Ainda a respeito das "raízes do Brasil", Gilberto Freyre ressalta uma miscigenação entre os portugueses colonizadores do Brasil,

[...] homens morenos de cabelo louro. Esses mestiços com duas cores de pelo é que formaram ao nosso ver, a maioria dos português colonizadores do Brasil, nos séculos XVI e XVII, e não nenhuma elite loura ou nórdica, branca pura: nem gente toda morena e de cabelo preto (FREYRE, 2006, p. 281).

Gilberto Freyre afirma uma presença árabe no cotidiano brasileiro, presença vinda com os colonizadores que conviveram com a cultura árabe na Península Ibérica por oito séculos.

O que a cultura peninsular, no largo trecho em que se exerceu o domínio árabe ou mouro [...] guardou da cultura dos invasores é o que hoje mais diferencia e individualiza esta parte da Europa. Conservados em grande parte pelos vencidos a religião e o direito civil, nas demais esferas da vida econômica e social a influência, árabe em certos trechos, em outros moura, foi profunda a intensa. 0 grosso da população hispano-romano-goda, excluída somente irredutível minoria refugiada em Astúrias, deixou-se impregnar nos seus gostos mais íntimos da influência árabe ou moura. Quando essa maioria acomodativa refluiu à Europa cristã, sob a forma de moçárabe, foi para constituir em Portugal o substrato mesmo da nacionalidade. [...] Quando aquela população socialmente móvel, mobilíssima mesmo, voltou à Europa cristã, foi trazendo consigo uma espessa camada de cultura e uma enérgica infusão de sangue mouro 


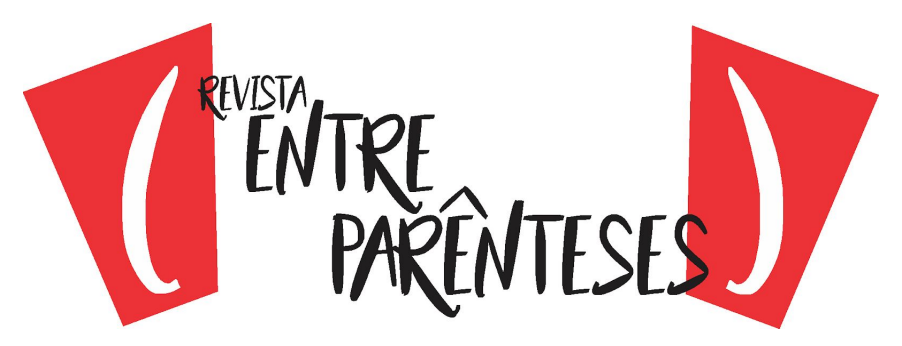

e negro que persistiriam até hoje no povo português e no seu caráter. Sangue e cultura que viriam ao Brasil; que explicam muito do que no brasileiro não é europeu, nem indígena, nem resultado do contato direto com a África negra através dos escravos. Que explicam o muito de mouro que persistiu na vida íntima do brasileiro através dos tempos coloniais. Que ainda hoje persiste até mesmo no tipo físico (FREYRE, 2006, p. 287-288).

Desta forma, a presença da cultura árabe é notada de diversas formas na Península Ibérica e posteriormente no Brasil. Esta presença é notada principalmente na culinária, religião, língua, arquitetura, técnicas agrícolas, etc.

Como ressalta Macedo o mouro viajou na memória dos europeus rumo ao “Novo Mundo". Macedo resgatando Câmera Cascudo (1943, p. 17-52) diz:

a interferência das tradições concernentes aos mouros em nossas origens não se limitou ao ritual. As trocas estabelecidas já na península lbérica entre as populações afro-muçulmanas e luso-espanholas parecem ter sido mais profundas do que se pode pensar. O convívio secular fez com que certos traços sociais mouros penetrassem nas formas culturais ibéricas, perpassando os hábitos e costumes transportados ao Brasil. Tais traços podem ser verificados em nosso vocabulário, indumentária, em nossa tradição oral e criações literárias eruditas, em nossa gestualidade e em certos aspectos de nosso comportamento coletivo (MACEDO, 2004, p. 145).

Neste mesmo sentido Portugal conclui que:

Com a chegada dos portugueses ao Brasil, grande parte da influência oriental, impregnada em seus hábitos, foi trazida para cá. Devido às diferentes condições de vida que o português encontrou aqui, essas influências orientais muitas vezes passaram por adaptações e readaptações, sendo que nem tudo foi assimilado. Podemos concluir que os hábitos e técnicas árabes aqui adotados, mesmo que não em toda a sua plenitude, tem grande representatividade (PORTUGAL, 2011, p.18).

A presença de uma cultura árabe no Brasil é notada de diversas formas.

Partido da perspectiva de que aspectos culturais presente na formação do homem 


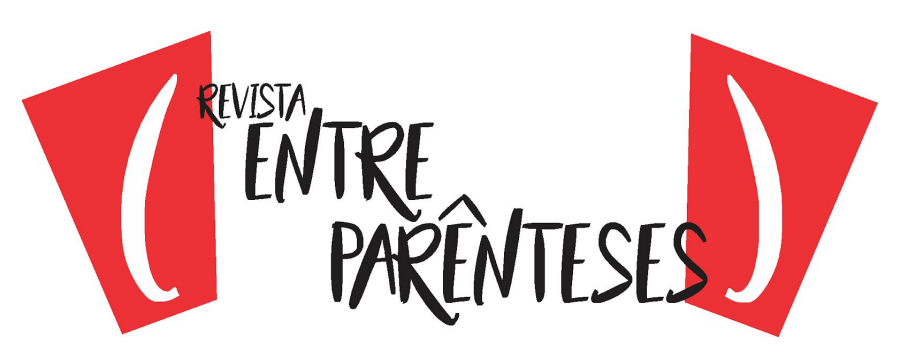

brasileiro têm suas raízes em Portugal. A influência árabe tornou-se visível em vários aspectos da sociedade Ibérica como na arquitetura, na arte, na medicina, na química, na astronomia, na ciência, na culinária, na religião, na formação da língua portuguesa, entre outras formas de presença, sendo que esta herança moura ${ }^{8}$ deixada na Península Ibérica, posteriormente é trazida para a América Portuguesa na memória de portugueses e espanhóis.

Há o registro de dois movimentos marcantes da presença árabe no Brasil, o primeiro é através do colonizador português e espanhol e mais tarde, no final do século XIX, com a chegada de imigrantes sírios e libaneses. A presença da cultura árabe - não só no Brasil como em toda a América - antecede o final do século XIX, pois

antes disso, ela esteve presente desde o início da colonização portuguesa, manifesta na língua, na música, na culinária, na arquitetura e decoração, nas técnicas agrícolas e de irrigação, na farmacologia e na medicina. É que os árabes dominaram por quase oito séculos a Península Ibérica, assinalando uma presença inolvidável em nossos colonizadores (TRUZZI, 2007, p. 360).

Graça a convivência entre árabes e a população da Península Ibérica ocorreram às trocas culturais, visto que a cultura árabe foi assimilada por estas populações peninsular e posteriormente recebemos toda esta cultura de forma indireta, pela obra colonizadora portuguesa e espanhola. Conforme Truzzi (2007), entre os aspectos culturais que vieram para o Brasil podemos destacar: a influência na língua portuguesa, os algarismos arábicos, o jogo de xadrez, a arte caligráfica, na culinária o uso do café, de doces próprios e produtos de pastelaria, o azeite, temperos como o açafrão, a noz moscada, o cravo, a canela, pimenta, entre outros

\footnotetext{
8 "O termo mouro, utilizado em um sentido amplo para definir os invasores da península lbérica, refere-se, a povos de várias origens, mas, sobretudo, aos habitantes islâmicos do norte da África" (ALVES, 2010, p. 14). "Mouros são afinal, com alguma consistência, as populações muçulmanas: os dominadores árabes, os berberes islamizados, os muçulmanos que se conservam na península depois da conquista cristã ou os que os navegadores vão reencontrar, a partir do século XV, nas suas expedições em África e Ásia" (MOREIRA, 2005, p. 79 apud ALVES, 2010, p. 15).
} 


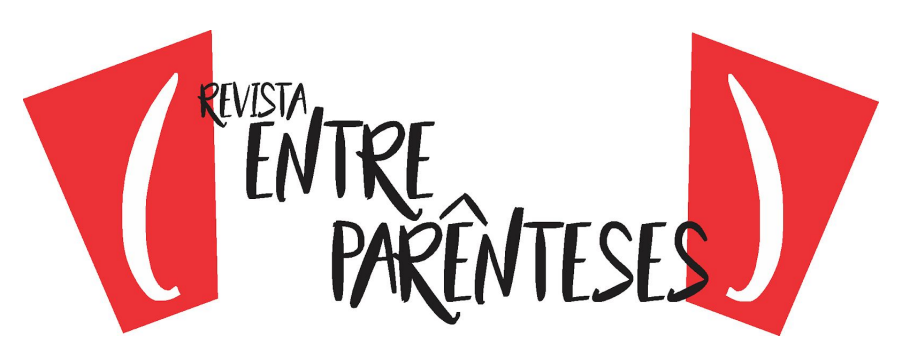

condimentos, na música a influência em diversos instrumentos, influências em técnicas construtivas, na arquitetura e na decoração presente até os dias atuais, a religião islâmica, a dança do ventre, entre outras expressões culturais. Neste mesmo sentido, Gilberto Freyre (2006, p. 294) ressalta que

os árabes trouxeram também à Europa o algodão, a laranjeira, a sericicultura, o cultivo do arroz e da cana-de-açúcar, esta tão fundamental à obra inicial de nossa colonização. E a aridez dos solos desérticos capacitou-os como mestres nas técnicas agrícolas e de irrigação, importando à Europa o moinho d'água, avô do engenho colonial brasileiro.

Quando falamos de Portugal e respectivamente de suas colônias há uma miscigenação de seus povos. O português além de seu sangue europeu é composto também por sangue árabe, originando uma hibridização cultural. Assim, o Brasil não é puramente português, pois, conforme Freyre,

[...] o ponto a destacar é a presença, não esporádica porém farta, de descendentes de moçárabes (...) entre os povoadores e primeiros colonizadores do Brasil. Através desse elemento moçárabe é que tantos traços de cultura moura e mourisca se transmitiram ao Brasil. Traços de cultura moral e material. (FREYRE, 2006, p. 298).

Desta forma, diversas pesquisas ressaltam distintas presenças culturais árabes no Brasil vindas anteriormente ao grande fluxo migratório do final do século XIX. Visto que as relações culturais ocorridas na Península Ibérica no decorre de oito séculos de presença árabe são visíveis na construção de uma identidade nacional brasileira. Assim não se pode referir apenas a uma influência árabe a partir da segunda metade do século XIX com a chegada da leva de imigrantes, principalmente de sírios e libaneses.

\section{CONSIDERAÇÕES FINAIS}




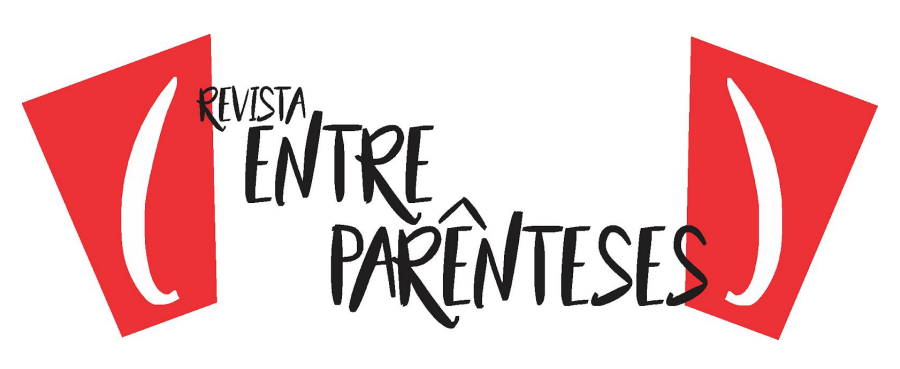

Entre as diferentes contribuições árabes para a formação cultural do Brasil, aspectos relacionados à arquitetura, culinária, vocabulário, religião, técnicas agrícolas, entre outras, estiveram presentes e ainda permanece presente na construção da identidade brasileira. Isto foi o que percebemos por meio da leitura de pesquisas de historiadores, antropólogos e sociólogos que trabalham com essa temática. No entanto, os estudos que focalizam esta questão de maneira aprofundada ainda são escassos, o que fortalece a concepção de uma constituição étnica e cultural brasileira a partir dos portugueses cristãos, dos indígenas nativo e dos africanos, ficando a contribuição árabe relegada a um segundo plano.

Ademais, observamos que a História lbérica é carente de produção. Há um silêncio do tema e uma lacuna a referências de uma influência cultural árabe em nossas raízes e um dos motivos deste silêncio é o viés historiográfico adotado por pesquisadores, sendo necessário descolonizar o ensino de história, que seria abordar a história por outro viés que não seja pela história europeia, enfatizando, por exemplo, a História Ibérica e construindo uma consciência histórica com relação a nossas raízes culturais que é na Península lbérica. Outro fator que corrobora com o silêncio da História Ibérica é o fato dos docentes da educação básica terem pouco conhecimento sobre o assunto, porque é algo que pouco se estudaram na academia.

\section{REFERÊNCIAS}

ABBAGNANO, Nicola. Dicionário de Filosofia. 3. ed. São Paulo: Martins Fontes, 1998.

AGNOLIN, Adone. O apetite da antropologia. O sabor antropofágico do saber antropológico: alteridade e identidade no caso tupinambá. São Paulo: Associação Editorial Humanitas, 2005. 


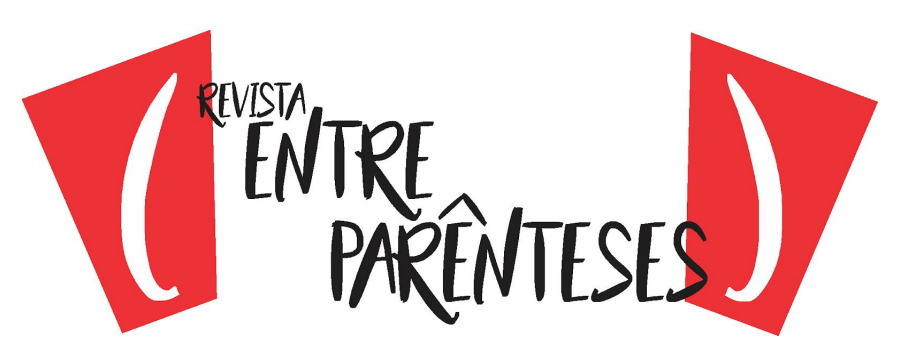

ALFONSO-GOLDFARB, A. M. Atanadores, cimitarras, minaretes: cultura árabe como tecido do saber sob o céu "medieval". Revista da SBHC, Rio de Janeiro, v. 5, n. 5, p. 33-40, jan/jun. 1991.

ALVES, Carla Carvalho. Figurações do mouro na literatura portuguesa: o lado errado no marenostro? 2010. 235 f. Tese (Doutorado em Literatura Portuguesa) Faculdade de Filosofia, Letras e Ciências Humanas, Universidade de São Paulo, São Paulo, 2010.

BISCARDI, K. Análise comparativa do pensamento de Sérgio Buarque de Holanda em Raízes do Brasil e Gilberto Freyre em Casa Grande \& Senzala. Revista Tempo de Conquista, v. 2, p. 1-12, 2007.

BUARQUE DE HOLLANDA, Sérgio. Raízes do Brasil. Rio de Janeiro, José Olympio, 1936.

CÂMARA CASCUDO, Luís da. Presença moura no Brasil. Rio de Janeiro: Editora Letras e Artes, 1967.

COSTA, Sandra. O Islão em Portugal. In: PINTO, Maria do Céu. O Islão na Europa. Lisboa: Editora Prefácio, 2006. p. 155-174. Disponível em: $<$ http://www.academia.edu/6073332/O_Isl\%C3\%A3o_em_Portugal_Islam_in_Portug al>. Acesso em: 11 abr. 2018.

Dicionário de Psicologia. São Paulo: Itamaraty, v.5, 1973.

FRANCO JÚNIOR, Hilário. Raízes medievais do Brasil. Revista USP, São Paulo, n. 78, p. 80-104, jun./ago. 2008. Disponível em: <http://www.revistas.usp.br/revusp/article/viewFile/13680/15498>. Acesso em: 10 abr. 2018.

FREYRE, Gilberto. Casa Grande \& Senzala: formação da família brasileira sob o regime de economia patriarcal. São Paulo: Global, 2006.

HOLANDA, Aurélio B. Dicionário da Língua Portuguesa. 6. ed. Curitiba: Positivo, 2004.

HOURANI, Albert. Uma história dos povos árabes. São Paulo: Cia das Letras, 2006.

MACEDO, José Rivair. Mouros e cristãos: a ritualização da conquista no velho e no novo mundos. Métis: história \& cultura, v. 3, n. 6. p. 129-151, 2004. Disponível em: 


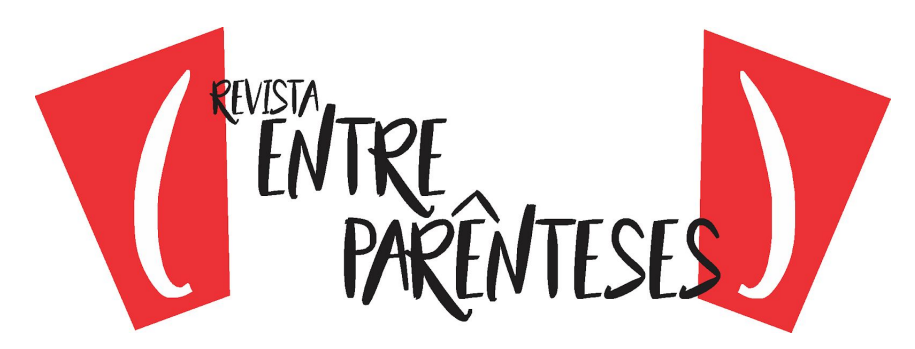

http://www.ucs.br/etc/revistas/index.php/metis/article/view/1163/801. Acesso em: 11 mar. 2018.

MORENO, Eduardo Manzano. Conquistadores, emires y califas. Barcelona: Crítica, 2011.

NOGUEIRA, Carlos Roberto F. A Reconquista ibérica: A construção de uma ideologia. Historia. Instituciones. Documentos, n. 28, p. 277-295, 2001. Disponível em: <https://dialnet.unirioja.es/servlet/articulo?codigo $=625181>$. Acesso em: 05 jan. 2018.

PORTUGAL, Ana Raquel M. da C. M. O legado árabe no Brasil. Ibérica, Juiz de Fora, v. 5, n. 16, p. 4-21, maio/ago. 2011. Disponível em: <http://www.academia.edu/2388676/O_LEGADO_\%C3\%81RABE_NO_BRASIL>. Acesso: 11 mar. 2018.

REIS, J. C. As identidades do Brasil: de Varnhagen a FHC. Rio de Janeiro: FGV, 1999b.

RUCQUOI, Adeline. História medieval da Península Ibérica. Lisboa: Editorial Estampa, 1995.

SILVEIRA, A. D. Europeização e/ou Africanização da Espanha Medieval: diversidade e unidade cultural europeia em debate. História, Franca, v. 28, n. 2, 2009. Disponível em: <http://www.scielo.br/pdf/his/v28n2/22.pdf>. Acesso em: $27 \mathrm{abr}$. 2018.

. Fronteiras da tolerância e identidades na Castela de Afonso X. In: FERNANDES, F. R. Identidade e fronteiras no medievo ibérico. Curitiba: Juruá Editora, 2013.

TRUZZI, Oswaldo. Presença Árabe na América do Sul. História Unisinos, São Leopoldo, v. 1, n. 3, p. 359- 366, set./dez. 2007.

Recebido em: 30/09/2019

Aceito em: 27/01/2019 